\title{
Analyzing the Importance of User Competency to the Effectiveness of Accounting Information System in Banking Sector
}

\author{
Ita Salsalina Lingga* \\ Accounting Program, Faculty of Economics \\ Maranatha Christian University \\ Bandung, Indonesia \\ *ita.salsalina@gmail.com
}

\begin{abstract}
Information technology is developing very fast now. In this fourth Industrial Revolution, technological development plays an important role in organization. In order to be able to survive, especially in the midst of today's world that increasingly rely on information technology, every organization need Accounting Information System. As a business strategy, Accounting Information System must be supported by competent employees. In other words, without an adequate user competency it is impossible to have an effective Accounting Information System. This research aims to analyse the effect of user competency on the effectiveness of Accounting Information System. Data collection in this descriptive survey research uses questionnaires which were distributed to regional banks located in 24 provinces in Indonesia. Total 176 questionnaires were collected from manager and staff related to accounting. Analysis of data uses Smart Partial Least Square (PLS). Based on the results of this study it can be concluded that user competency affects the effectiveness of Accounting Information System. The results show that inadequate knowledge and skills possessed by the employees will give an impact to the effectiveness of the Accounting Information System. Thus, it is necessary for all banks to increase knowledge and skills of their employees as user of Accounting Information System so they are able to compete. This finding are in line with previous research and support the theory.
\end{abstract}

Keywords-user competency, knowledge, skills, accounting information system

\section{INTRODUCTION}

Information technology is developing rapidly especially in this era of industrial revolution 4.0. This causes an impact to all organizations from small to large scale. In order to be able to survive and compete, an organization increasingly relies on information technology especially accounting information system [1-4]. Therefore, accounting information system is designed as a competitive strategy to support business processes and operations as well as decision making.

As the main system in organization, an accounting information system aims to provide information needed by stakeholders [1,5]. In other words, accounting information system is processing data transactions into financial information, and distributing it to interested parties (stakeholders). The effectiveness of an accounting information system can be measured by its ability to achieve organizational goals or meet user needs [3,5-8].

In reality, there are some problems in various business sectors in Indonesia due to ineffectiveness of accounting information system. These problems related to integration, reliability, flexibility, and usability. Ineffectiveness of accounting information system is affected by several factors. According to Siegel and Marconi, accounting information system are associated with social science (behavioural theory) [9]. Therefore, behavioural aspect for example user competency is one of factors that affect the effectiveness of accounting information system [10].

According to Ward and Peppard if accounting information system has a strategic role in business, then the business should develop and maintain a high level of competency in managing and using accounting information system [11]. In other words, weaknesses in each area of competency will affect the ability of accounting information system, which in turn gives impact on business operations both directly and indirectly [11]

Competency is defined as characteristics possessed and used by individuals in an appropriate and consistent manner in the context of achieving the expected performance [12]. In addition, competency is also interpreted as a combination of knowledge, skills, experience and behaviour of an individual [11]. Competency consist of knowledge and skills needed, so that someone can complete his work assignments. In line with this, Beardwell and Claydon stated that competency is the ability to apply knowledge and skills in understanding work activities [13]. The combination of user knowledge and experience are the best solution $[8,14]$.

On of factors that cause ineffectiveness of accounting information systems is low of competency or inadequate quality of human resources [15-17]. Previous studies proved that user competency influences the effectiveness or successful implementation of accounting information system [18-22]. Survey in this research focuses on Regional Development Bank (BPD Bank) seen from integration, reliability [15,23], flexibility [24,25], and usability [26]. 


\section{LITERATURE REVIEW}

\section{A. User Competency}

Competency is a fundamental characteristic of a person or ability possessed by someone which is used to complete the task or achieve the expected performance [12,27-29]. Competency is defined as a combination of knowledge, skills, behaviours and attitudes that enable a person to do a job [13,30-32]. The combination of knowledge and skills is very important because it will determine one's success in interacting with accounting information systems $[5,33]$.

User competency is very important because the majority of users are people who spend a lot of time communicating and collaborating in teams while using information systems or information produced by this information system [3,14,34-36]. Thus what is meant by user competency in the context of this research is a fundamental characteristic of a person especially a combination of knowledge and skills possessed by user who directly interacts with the accounting information system to enable this user to complete his task properly.

Knowledge is more clearly interpreted as something that can be learned, both in formal education and reading and observing [27,37-39] while Noe et al [31] and Stair and Reynolds [3] define knowledge as a collection of facts or information in the form of procedures needed to support task completion well.

There are two types of knowledge, namely tacit knowledge and explicit knowledge. Tacit knowledge is a knowledge that is formed through experience. It is a direct action that is not documented and generally shared through conversation, whereas explicit knowledge is a knowledge that is stored in documents such as reports and guidelines, books, magazines, journals, or other media that are generally easy to articulate and shared with other parties [30,39-41].

Furthermore, skills are defined as the ability of a person to complete certain tasks according to his expertise [27,31,42]. There are two types of skills, namely conceptual skills and technical skills. Conceptual skills are the ability to work with and through others effectively as team members, where these skills are reflected through the ability to motivate, facilitate, coordinate, lead, communicate and resolve conflicts [43]. Technical skill is the ability in terms of understanding and mastery to carry out certain tasks, which includes mastery of methods, techniques and equipment used in certain functions [30,39-42]. This technical skill is important to be owned by every employee whose job is related to information systems [3].

\section{B. Effectiveness of Accounting Information Systems}

Some experts define accounting information system as (1) data sets and processing procedures that produce information for users [6], (2) subsystems of information system that aim to collect, process and report financial information from business transactions [1], (3) a collection of human resources and equipment, designed to convert financial data and other data into information used by decision makers [2], (4) the process of collecting and processing business transaction data into a report that is useful for decision makers decisions [44], (5) systems for collecting, recording, storing, and processing data to produce information for decision makers [5].

According to Leitch and Davis the success of a system is measured by the integration between sub-systems/components [45]. In addition, the effectiveness of a system can be measured by its ability to meet user needs, the ability to achieve goals, the ability to meet user satisfaction, and the ability to meet quality standards [3,7]. This is known as the success model of information systems.

The most important factor for the effectiveness of an accounting information system is the purpose of its system [5]. This was also stated by Boczko that the purpose of accounting information systems is to facilitate data collection, data maintenance, data management, data control and information presentation procedures [46]. In other words, the effectiveness of accounting information system is measured based on integration, reliability, flexibility, and usability.

Integration is assessed based on the integration between sub systems and systems [34,45-51]. The reliability of a system is measured by the ability of the system to function properly starting from data input, processing to produce accounting information (output) and the ability of the system to produce accurate accounting information. Flexibility is assessed from the ability of the system to adapt to the change of conditions/environment and the ability of the system to adapt to the change of needs or business [6,46,48,50,52-54]. Furthermore, usability is assessed from the ease of use and the ease of learning $[50,52]$.

\section{Effect of User Competence on the Effectiveness of Accounting Information Systems}

An accounting information system can be implemented effectively if the user has the necessary and competent knowledge and skills [51,55]. In other words, the low competency of users in the form of knowledge and skills are the main factors that cause ineffective accounting information system which in turn give an impact on business performance [11]. Furthermore, Ward and Peppard noted that weakness in each area of competence related to accounting information systems will affect the ability of the accounting information system, which will give impact on business operations and ultimately affect the performance of its business [11]. The same thing was stated by O'Brien and Marakas (2010) that accounting information system will not give benefit to the organization if it is not supported by knowledgeable employees [14]. This means that an accounting information system needs a competent worker with an adequate knowledge, skills and abilities in order to work properly [56].

The above theory is reinforced by the results of previous studies. According to Daoud and Triki the competency of accounting staff influences the success of accounting information system [57]. Furthermore, Afiah and Indahwati prove that user competency influences the quality of accounting information system [20]. Likewise, Nurhayati and Mulyani [19] and Napitupulu and Dalimunthe [21] prove that user competency influences the successful application of accounting information system. The same thing was also stated by Mulyani and Enggar that manager's competency has an 
impact on the quality of accounting information produced by the accounting information system [22].

Based on the theories that have been explained above and results of some previous research, it can be said that user competency influences the effectiveness of accounting information system [56]. Thus the conceptual framework of this research can be described as in figure 1 .

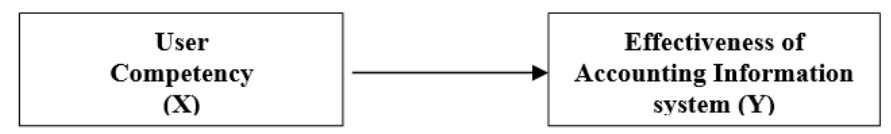

Fig. 1. Conceptual framework.

The hypotheses proposed in this study are $\mathrm{H} 1$ : user competency affects the effectiveness of accounting information system.

\section{MATERIALS AND MethoD}

This research is categorized as descriptive and explanatory research [58], which is intended to explain the causal relationship and hypothesis testing [59]. Thus this study aims to examine the influence of user competency to the effectiveness of accounting information system.

Unit of analysis in this study is regional banks (BPD Banks) in all provinces in Indonesia and unit of observation is accounting and operational division of each BPD Banks. Furthermore, the respondents in this research are head of accounting division and other related staff as users of accounting information system.

Validity testing in this research is intended to find out whether the questionnaire is able to measure the concept of its variable while the reliability testing is intended to determine the consistency of its concept measurement [60]. According to Kaplan and Saccuzzo [61], an instrument is said to be valid if validity coefficient is $\geq 0.30$, while to be reliable if reliability coefficient is $>0.70$. According to Sekaran Bougie, if Cronbach alpha coefficient $<0.6$ it means that reliability is categorized as poor, then if Cronbach alpha coefficient is $=0.7$ it means that reliability is categorized as acceptable whereas if Cronbach alpha coefficient $>0.8$ it means that reliability is categorized as good [58].

Data analysis in this study uses Partial Least Square SEM (PLS SEM). The statistical hypothesis testing in this study are as follows:

- Ho: $\gamma 1=0$ User Competency does not affect the Effectiveness of Accounting Information System.

- $\mathrm{H} 1: \gamma 1 \neq 0$ User Competency affects the Effectiveness of Accounting Information Systems.

\section{RESULTS AND DISCUSSION}

In this research, the distribution of questionnaires was distributed to 27 Regional Development Banks (BPD Banks) from head office, branch offices to sub-branch offices. The observation units in this study are head of accounting division together with operational staff. The total number of questionnaires distributed were 275 , while return rate of questionnaires from 24 BPDs was 64\% (176 questionnaires). This shows the fulfilment of minimum requirements of $30 \%$ $[58,62]$.

Validity testing in this research uses product moment correlation while reliability testing uses Alpha-Cronbach method. Statement items are declared valid if the correlation coefficient $\geq 0.30$ and statement items are declared reliable if the reliability coefficient $\geq 0.70$ [61]. Data analysis shows the following results in table 1 :

TABLE I. RECAPITULATION OF TEST RESULTS FOR VALIDITY AND RELIABILITY

\begin{tabular}{|c|c|c|c|}
\hline Variable & Statement & Validity & Reliability \\
\hline \multirow{4}{*}{$\begin{array}{l}\text { User } \\
\text { Competency }\end{array}$} & Item 1 & 0,730 & \multirow{4}{*}{0,892} \\
\hline & Item 2 & 0,805 & \\
\hline & Item 3 & 0,775 & \\
\hline & Item 4 & 0,747 & \\
\hline \multirow{8}{*}{$\begin{array}{l}\text { Effectiveness of } \\
\text { Accounting } \\
\text { Information } \\
\text { System }\end{array}$} & Item 5 & 0,696 & \multirow{8}{*}{0,914} \\
\hline & Item 6 & 0,743 & \\
\hline & Item 7 & 0,673 & \\
\hline & Item 8 & 0,726 & \\
\hline & Item 9 & 0,770 & \\
\hline & Item 10 & 0,707 & \\
\hline & Item 11 & 0,730 & \\
\hline & Item 12 & 0,704 & \\
\hline
\end{tabular}

Before data analysis is performed, we conduct average categorization of respondent's score based on maximum and minimum score range which are divided by numbers of desired categories. If the score interval shows (1) between 1.00-1.99 it means the category is not good/bad, (2) between 2.00-2.99 it means less good, (3) between 3.00-3.99 it means average/sufficient, (4) between 4.00-5.00 it means good.

The following table 2 below presents recapitulation of respondents' responses average score of user competency dimension:

TABLE II. RECAPITULATION OF RESPONDENTS' RESPONSES AVERAGE SCORE OF USER COMPETENCY DIMENSION

\begin{tabular}{|c|c|c|c|c|c|c|c|}
\hline No & Dimension & $\begin{array}{l}\text { Real } \\
\text { Score }\end{array}$ & $\begin{array}{l}\text { Total } \\
\text { Score }\end{array}$ & Average & $\begin{array}{c}\text { \% Real } \\
\text { Score: } \\
\text { Total }\end{array}$ & $\underset{\%}{\text { Gap }}$ & Category \\
\hline 1 & Knowledge & 179 & 240 & 3,73 & 74,58 & 25,42 & Average \\
\hline 2 & Skills & 177 & 240 & 3,69 & 73,75 & 26,25 & Average \\
\hline & al average & 356 & 480 & 3,71 & 74,17 & \multirow{3}{*}{\multicolumn{2}{|c|}{ Average }} \\
\hline \multirow{2}{*}{\multicolumn{4}{|c|}{ Gap }} & 1,29 & 25,83 & & \\
\hline & & & & & 100 & & \\
\hline
\end{tabular}

Source: results of data processing

Based on table 2 it can be seen that user competency has mean score 3,71. It means that user competency is categorized as average. Therefore, in general employee competency in BPD Banks only reach average level not yet in good level.

Table 3 below presents recapitulation of respondents' responses average score regarding indicators of user 
competency at 24 Regional Development Bank (BPD Banks) from all of provinces in Indonesia.

TABLE III. RECAPITULATION OF RESPONDENTS' RESPONSES AVERAGE SCORE REGARDING INDICATORS OF USER COMPETENCY AT 24 BPD BANKS

\begin{tabular}{|c|l|c|c|c|c|c|c|c|c|c|}
\hline \multirow{2}{*}{ No } & \multirow{2}{*}{ Indicators } & \multicolumn{2}{|c|}{ Good } & \multicolumn{2}{|c|}{ Average } & \multicolumn{2}{|c|}{ Low } & \multicolumn{2}{|c|}{ Bad } & Total \\
\cline { 3 - 10 } & Total & $\%$ & Total & $\%$ & Total & \% & Total & \% & BPD \\
\hline 1 & $\begin{array}{l}\text { Explicit } \\
\text { Knowledge }\end{array}$ & 8 & 33 & 16 & 67 & 0 & 0 & 0 & 0 & 24 \\
\hline 2 & $\begin{array}{l}\text { Tacit } \\
\text { Knowledge }\end{array}$ & 7 & 32 & 15 & 68 & 0 & 0 & 0 & 0 & 24 \\
\hline 3 & $\begin{array}{l}\text { Conceptual } \\
\text { skills }\end{array}$ & 5 & 21 & 19 & 79 & 0 & 0 & 0 & 0 & 24 \\
\hline 4 & $\begin{array}{l}\text { Technical } \\
\text { skills }\end{array}$ & 6 & 25 & 18 & 75 & 0 & 0 & 0 & 0 & 24 \\
\hline
\end{tabular}

Based on data in table 3, it can be seen that from 24 BPD Banks being surveyed, most of BPD Banks only have employees with average competency. The details are as follows: (1) for the knowledge dimension, 16 BPD (67\%) have average explicit knowledge, 8 BPD (33\%) have good explicit knowledge; 15 BPD (68\%) have average tacit knowledge and 7 BPD $(32 \%)$ have good tacit knowledge; (2) for the skill dimensions of 19 BPD (79\%) have average conceptual skills; 5 BPD (21\%) have good conceptual skills; 18 BPD (75\%) have average technical skills and 6 BPD (25\%) have good technical skills.

The following is a recapitulation of respondents' responses average score for each dimension of the effectiveness of accounting information system as stated in table 4 below:

TABLE IV. RECAPITULATION OF RESPONDENTS' RESPONSES AVERAGE SCORE FOR EACH DIMENSION OF THE EFFECTIVENESS OF ACCOUNTING INFORMATION SYSTEM

\begin{tabular}{|c|c|c|c|c|c|c|c|}
\hline No & & $\begin{array}{c}\text { Real } \\
\text { Score }\end{array}$ & $\begin{array}{l}\text { Total } \\
\text { Score } \\
\end{array}$ & Average & $\begin{array}{c}\% \text { Real } \\
\text { Score: Total }\end{array}$ & $\begin{array}{c}\text { Gap } \\
\%\end{array}$ & Category \\
\hline 1 & Integration & 179 & 240 & 3,73 & 74,58 & 25,42 & Average \\
\hline 2 & Reliability & 183 & 240 & 3,81 & 76,25 & 23,75 & Average \\
\hline 3 & Flexibility & 172 & 240 & 3,58 & 71,67 & 28,33 & Average \\
\hline 4 & $\begin{array}{l}\text { Usability } \\
\end{array}$ & 185 & 240 & 3,85 & 77,08 & 22,92 & Average \\
\hline \multicolumn{2}{|c|}{ Total Average } & 719 & 960 & 3,74 & 74,90 & \multirow{3}{*}{\multicolumn{2}{|c|}{ Average }} \\
\hline \multirow{2}{*}{\multicolumn{4}{|c|}{$\frac{\text { Gap }}{\text { Total }}$}} & 1,26 & 25,10 & & \\
\hline & & & & & 100 & & \\
\hline
\end{tabular}

Source: results of data processing

Based on data in table 4, it can be seen that the effectiveness of accounting information system has a mean score of 3.74, which is in average category. It can be seen that in general the implementation of accounting information system in BPD is not effective but still in average category.

TABLE V. RECAPITUlation OF RESPONDENTS' AVERAGE SCORE RESPONSES FOR INDICATORS OF EFFECTIVENESS OF ACCOUNTING INFORMATION SySTEMS AT 24 BPD

\begin{tabular}{|c|c|c|c|c|c|c|c|c|c|c|}
\hline \multirow{2}{*}{ No } & \multirow{2}{*}{ Indicator } & \multicolumn{2}{|c|}{ Good } & \multicolumn{2}{|c|}{ Average } & \multicolumn{2}{|c|}{ Low } & \multicolumn{2}{|c|}{ Bad } & \multirow{2}{*}{$\begin{array}{l}\text { Total } \\
\text { BPD }\end{array}$} \\
\hline & & Total & $\%$ & Total & $\%$ & Total & $\%$ & Total & $\%$ & \\
\hline 1 & Integration between sub systems and system & 7 & 29 & 17 & 71 & 0 & 0 & 0 & 0 & 24 \\
\hline 2 & Integration between sub systems and environment & 7 & 29 & 17 & 71 & 0 & 0 & 0 & 0 & 24 \\
\hline 3 & $\begin{array}{l}\text { Accounting information system functions correctly starting from } \\
\text { inputting data, and processing to produce accounting information }\end{array}$ & 12 & 50 & 12 & 50 & 0 & 0 & 0 & 0 & 24 \\
\hline 4 & $\begin{array}{l}\text { Security of accounting information system functions starting from } \\
\text { inputing data and processing to produce accounting information }\end{array}$ & 7 & 29 & 17 & 71 & 1 & 4 & 0 & 0 & 24 \\
\hline 5 & The ability of the system to adapt to various needs of users & 7 & 29 & 17 & 71 & 0 & 0 & 0 & 0 & 24 \\
\hline 6 & $\begin{array}{l}\text { The ability of the system to adapt to changing conditions or } \\
\text { environment }\end{array}$ & 5 & 21 & 19 & 79 & 0 & 0 & 0 & 0 & 24 \\
\hline 7 & easy to use & 10 & 42 & 14 & 58 & 0 & 0 & 0 & 0 & 24 \\
\hline 8 & easy to learn & 8 & 33 & 16 & 67 & 0 & 0 & 0 & 0 & 24 \\
\hline
\end{tabular}

Based on the data in table 5 it can be seen that from 24 BPD surveyed, the effectiveness of AIS implementation in general was categorized as average. The details are as follows: (1) for integration dimensions of 17 BPD (71\%) have average integration between sub-systems and system and 7 BPD (29\%) have good integration between sub-systems and system; 17 BPD $(71 \%)$ have average integration between sub-systems and environment and 7 BPD (29\%) have good integration between sub-systems and environment; (2) for reliability dimensions of 12 BPD $(50 \%)$ have average security of accounting information system in terms of functioning correctly starting from inputting data, and processing to produce accounting information (output); 12 BPD (50\%) have good security of accounting information system in terms of functioning properly starting from inputting data, processing to produce accounting information (output); (2) for reliability dimension as many as 12 BPD $(50 \%)$ have average accounting information system in terms of functioning correctly starting from data input, processing to produce accounting information (output) and 12 BPD $(50 \%)$ have good accounting information system in terms of functioning properly starting from data input, processing to produce accounting information (output); then 17 BPD (71\%) have average security of accounting information system functions starting from inputting data, processing to produce accounting information (output) and 7 BPD (29\%) have good security of accounting information system functions starting from inputting data, processing to producing accounting information (output); (3) for flexibility dimension 17 BPD $(71 \%)$ has average ability of accounting information system to adapt to various needs of user and 7 BPD (29\%) have good ability of accounting information system to adapt to various needs of user; and 19 BPD $(79 \%)$ have average ability of accounting information system to adapt to changing conditions or environment and 5 BPD (21\%) have good ability of accounting information system to adapt to changing conditions or environment; (4) for usability dimensions 14 BPD (58\%) have accounting information system that is quite easy to use and as many as 10 BPD (42\%) have accounting information system that is very easy to use; 16 BPD $(67 \%)$ have accounting information system that is quite easy to learn and 8 BPD (33\%) have accounting information system that is very easy to learn.

Figure 2 below describe measurement model of latent variable (user competency) which is reflected in two dimensions and four indicators. 


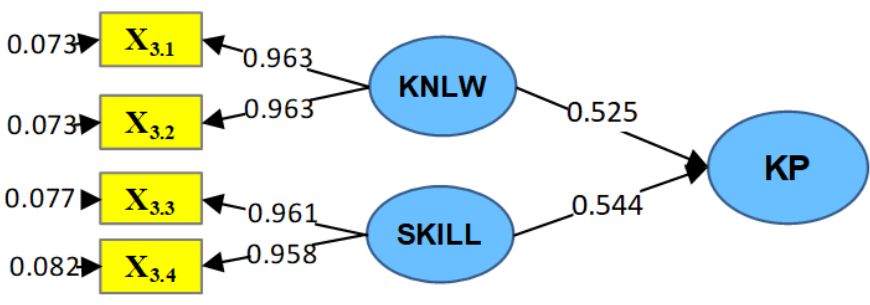

Fig. 2. Measurement model of user competency variables.

The results of data analysis using first order confirmatory factor analysis are presented in table 6 below:

TABLE VI. SUMmARY OF FIRST ORdER VALIDITy TeSt MEASUREMENT MODEL OF USER COMPETENCY VARIABLES

\begin{tabular}{|l|l|l|l|l|}
\hline No. & \multicolumn{1}{|c|}{ Indicator } & Loading Factor & CR & AVE \\
\hline 1 & Explicit knowledge & 0,963 & \multirow{2}{*}{0,962} & 0,927 \\
\cline { 1 - 3 } 2 & Tacit knowledge & 0,963 & \multirow{2}{*}{0,959} & 0,921 \\
\cline { 1 - 3 } 3 & Conceptual Skills & 0,961 & & \\
\hline 4 & Technical Skills & 0,958 & \multicolumn{3}{|c|}{ Source: data that has been processed }
\end{tabular}

Based on table 6 above, loading factor value for each indicator shows more than 0.50 . It can be concluded that all indicators are valid. From composite reliability (CR) value for each dimension $>0.70$, it can be concluded that all indicators are reliable. From loading factor value of knowledge dimension, it can be seen that tacit knowledge and explicit knowledge both equally strong in reflecting knowledge dimension. Furthermore, based on average variance extracted (AVE) value 0.927 , it can be concluded that $92.7 \%$ of information contained in each indicator can be reflected through knowledge dimension.

Likewise, from loading factor value of skill dimension, between two dimensions, conceptual skills provide greater contribution than technical skills. Furthermore, based on average variance extracted (AVE) value 0.921, it can be concluded that $92.1 \%$ of information contained in each indicator can be reflected through skills dimension.

The following Table 7 presents measurement model of user competency variable using second order analysis with formative model.

TABLE VII. SUMMARY OF SECOND ORDER VALIDITY TEST MEASUREMENT MODEL OF USER COMPETENCY VARIABLE

\begin{tabular}{|l|l|l|l|}
\hline \multicolumn{1}{|c|}{ Dimension } & \multicolumn{1}{|c|}{$\begin{array}{c}\text { Regression } \\
\text { Coefficient }\end{array}$} & \multicolumn{1}{c|}{ t-value } & \multicolumn{1}{c|}{$\mathbf{R}^{\mathbf{2}}$} \\
\hline Knowledge & 0,525 & 32,46 & 0,948 \\
\hline Skill & 0,544 & 15,59 & \\
\hline
\end{tabular}

Based on table 7 above, it can be seen that t-value of each dimension is greater than 1.96. It shows that both dimensions are significant in forming latent variables (user competency). From $\mathrm{R}^{2}$ value of 0.948 it can be seen that both dimensions contribute $94.8 \%$ in forming latent variables (user competency). Between two dimensions, skills dimension provides greater contribution in forming latent variable (user competency) than knowledge dimension.

\section{CONCLUSION AND SUGGESTIONS}

\section{A. Conclusion}

Based on finding results it can be concluded that user competency influences the effectiveness of accounting information system. This finding results support the theory. Ineffectiveness of accounting information system due to not being fully supported by employees who have adequate knowledge and skills.

\section{B. Suggestions}

Some suggestions to improve user competency include:

- Conduct an HR placement appropriately in the accounting department. Therefore, they must have an educational background in accounting and have adequate knowledge regarding accounting information system. Knowledge enhancement is carried out through higher level of study programs in the field of accounting as well as training related to accounting information system both for employees with accounting and nonaccounting backgrounds.

- Improve conceptual and technical skills for employees in accounting and operational division through ongoing training regarding information technology so that employees are able to use accounting information system effectively.

\section{REFERENCES}

[1] U.J. Gelinas and R.B. Dull, Accounting Information Systems. $7^{\text {th }}$ edition. Thomson South Western, 2008.

[2] G.H. Bodnar and W.S. Hopwood, Accounting Information Systems. $10^{\text {th }}$ edition. Pearson Education Inc, 2010.

[3] M. Ralph and G.W. Reynolds, Fundamentals of Information Systems. $8^{\text {th }}$ edition. Cengage Learning, 2016.

[4] J.A. O'Brien and G.M. Marakas, Management Information Systems. 10 edition. McGraw-Hill Companies, Inc, 2011.

[5] M.B. Romney and P.J. Steinbart, Accounting Information Systems. $13^{\text {th }}$ edition. Pearson Education Limited, 2015.

[6] N.A. Bagranoff, M.G. Simkin and C.S. Norman, Accounting Information Systems. 11 ${ }^{\text {th }}$ edition. John Wiley \& Sons, Inc, 2010.

[7] J. Fortune and G. Peters, Information Systems: Achieving Success By Avoiding Failure. John Wiley \& Sons, Ltd, 2005.

[8] K.C. Laudon and J.P. Laudon, Management Information Systems Managing The Digital Firm. Global Edition. $13^{\text {th }}$ edition. Pearson Education Ltd, 2014.

[9] G. Siegel and H.R. Marconi, Behavioral Accounting. South Western Publishing Co., 1989.

[10] K.E. Kendall and J.E. Kendall, Systems Analysis and Design. Pearson Education, Inc., 2011

[11] J. Ward and J. Peppard, Strategic Planning for Information Systems. $3^{\text {rd }}$ edition. John Wiley \& Sons, Ltd, 2002.

[12] D.D. Dubois and W.J. Rothwell, Competency-Based Human Resource Management. Davies-Black Publishing, 2004. 
[13] J. Beardwell and T. Claydon, Human Resource Management: A Contemporary Approach. $5^{\text {th }}$ edition. Pearson Education Limited, 2007.

[14] J.A. O'Brien and G.M. Marakas, Introduction to Information Systems. $15^{\text {th }}$ edition. McGraw-Hill Companies, Inc., 2010.

[15] I. Kelana, Menanti Gebrakan Transformasi BPD" [Online]. Retrieved from: http://www.republika.co.id/berita/koran/pareto/15/06/08/npmbo6menanti-gebrakan-transformasi-bpd, 2015.

[16] E. Pongosoda, Accessed on: http://ekonomi.metrotvnews.com/mikro/ Rb1lVPXN-ojk-transformasi-bpd-masih-terkendala, 2016.

[17] W. Goesti and N. Indrietta, Bank Pembangunan Daerah Benahi Sistem Informasi Nasabah [Online]. Retrieved from: https://m.tempo.co/read/news/2016/09/03/087801306/bankpembangunan-daerah-benahi-sistem-informasi-nasabah, 2016.

[18] H. Daoud and M. Triki, "Accounting Information Systems in an ERP Environment and Tunisian Form Performance," The International Journal of Digital Accounting Research, vol. 13, no. 19, pp. 1-35, 2013.

[19] N. Nurhayati and S. Mulyani, "User Participation on System Development, User' Competence and Top Management Commitmen and Their Effect on The Success of The Implementation of Accounting Information Systems (Empirical Study on Islamic Bank in Bandung), "European Journal of Business and Innovation Research, vol. 3, no. 2, pp. 56-68, 2015

[20] N.N. Afiah and R. Indahwati, “Top Management Suport and User's Competency on The Accounting Information Systems' Quality,' IJABER, vol. 13, no. 6, pp. 4049-4055, 2015.

[21] I.H. Napitupulu and A.R. Dalimunthe, "The Influence of Information System User Competency and The Quality of Management Accounting Information Systems on User Satisfaction," Australian Journal of Basic and Applied Sciences, vol. 9, no. 31, pp. 660-667, 2015.

[22] S. Mulyani and D.P.A. Enggar, "The Influence of Manager Competency and Internal Control Effectiveness Toward Accounting Information Quality,” IJABDER, vol. 14, no. 1, pp. 181-190, 2016.

[23] I. Irwanto, Bank Sumsel Babel digeledah polisi terkait kredit fiktif PT CT [Online]. Retrieved from: https://www.merdeka.com/peristiwa/banksumsel-babel-digeledah-polisi-terkait-kredit-fiktif-pt-ct.html, 2014

[24] A.M. Saefulloh, Kemenkeu Terlalu Memaksakan Diri, DJPB dan DJKN Harus Bertanggung Jawab [Online]. Retrieved from: https://www.kompasiana.com/ anangsaefulloh/kemenkeu-terlalumemaksakan-diri-djpb-dan-djkn-harus-bertanggungjawab 55959645337a614c068b456c, 2015.

[25] G. Yudistira, Panin Bank Syariah jalin kerjasama dengan Emerio [Online]. Retrieved from: http://keuangan.kontan.co.id/news/paninbank-syariah-jalin-kerjasama-dengan-emerio, 2014.

[26] D.M. Ramdan, Penerapan sistem bridging masih terkendala [Online]. Retrieved from: http://nasional.kontan.co.id/news/penerapan-sistembridging-masih-terkendala, 2014.

[27] L.M. Spencer and S.M. Spencer, Competence at Work: Models for Superior Performance. John Wiley \& Sons, Inc, 1993.

[28] P. Docherty and B. Nyhan, Human Competence and Business Development Emerging Patterns in European Companies. SpringerVerlag London Limited, 1997.

[29] J.H. Bernardin and J.E.A. Russell, Human Resource Management. $6^{\text {th }}$ edition. McGraw-Hill education, 2013.

[30] J.W. Slocum, S.E. Jackson and D. Hellriegel, Competency-Based Management. Thomson South-Western, 2008.

[31] R.A. Noe, J.R. Hollenbeck, B. Gerhart and P.M. Wright, Human Resource Management: Gaining A Competitive Advantage. $9^{\text {th }}$ edition. Mc. Graw-Hill Education, 2015

[32] J.M. Ivancevich and R. Konopaske, Human Resource Management. $12^{\text {th }}$ edition. McGraw-Hill Education, 2013.

[33] J. Valacich and C. Schneider, Information Systems Today: Managing in Digital World. $7^{\text {th }}$ edition. Pearson Education Limited, 2016.

[34] J.L. Whitten and L.D. Bentley, Systems Analysis and Design Methods. $7^{\text {th }}$ edition. McGraw-Hill, 2007.
[35] G. Piccoli, Essentials of information Systems for Managers. John Wiley \& Sons, Inc, 2012.

[36] A. James, Accounting Information Systems. $7^{\text {th }}$ edition. South Western, Cengage Learning, 2011.

[37] R. McLeod Jr and G.P. Schell, Management Information Systems. 10 edition. Pearson Prentice Hall, 2007.

[38] W.G. Zikmund, B.J. Babin, J.C. Carr and M. Griffin, Business Research Methods. $9^{\text {th }}$ edition. South-Western, Cengage Learning, 2013.

[39] P. Bocij, A. Greasley and S. Hickie, Business Information Systems: Technology, Development and Management for the E-Business. $5^{\text {th }}$ edition. Pearson Education Ltd, 2015.

[40] T.L. Wheelen and J.D. Hunger, Strategic Management and Business Policy: Toward Global Sustainability. $13^{\text {th }}$ edition. Pearson Education, Inc., 2012.

[41] G.G. Dess, G.T. Lumpkin, A.B. Eisner and G. McNamara, Strategic Management: Creating Competitive Advantages. $7^{\text {th }}$ edition. Global Edition. McGraw-Hill Education Ltd., 2014.

[42] A.A. Vass, Social Work Competencies: Core Knowledge, Values and Skills. SAGE Publications, 2004.

[43] R.L. Daft, Management. $8^{\text {th }}$ edition. Thomson South Western, 2008

[44] J.W. Wild, K.W. Shaw and B. Chiappetta, Fundamental Accounting Principles. $20^{\text {th }}$ edition. McGraw-Hill, 2011

[45] R.A. Leitch and K.R. Davis, Accounting Information Systems: Theory and Practice. Prentice-Hall International, Inc., 1992.

[46] T. Boczko, Corporate Accounting Information Systems. $7^{\text {th }}$ edition. Pearson Education Ltd, 2007.

[47] F.H. Wu, Accounting Information Systems: Theory and Practice. McGraw-Hill, Inc., 1983.

[48] J.F. Nash and M.B. Roberts, Accounting Information Systems. Macmillan Publishing Company, 1984.

[49] M. Heidmann, The Role of Management Accounting Systems in Strategic Sensemaking. $1^{\text {st }}$ edition.Germany: Deutscher UniversitatsVerlag, 2008

[50] P. Baltzan and A. Phillips, Essentials of Business Driven Information Systems. McGraw-Hill Irwin, 2009.

[51] R.M. Stair and G.W. Reynolds, Fundamentals of Information Systems. $5^{\text {th }}$ edition. Course Technology, Cengage Learning, 2010.

[52] C. Avgerou and T. Conrnford, Developing Information Systems: Concepts, Issues and Practice. $2^{\text {nd }}$ edition. Palgrave Macmillan, 1998.

[53] W.H. DeLone and E.R. McLean, "The DeLone and McLean Model of Information Systems Success: A Ten-Year Update," Journal of Management Information Systems. Spring 2003, vol. 19, no. 4, pp. 9 30, 2003.

[54] P. Baltzan, Business Driven Information Systems. $4^{\text {th }}$ edition. McGrawHill Irwin, 2014.

[55] S. Alter, Information Systems: The Foundation of E-Business. $4^{\text {th }}$ edition. International Edition. Pearson Education Inc., 2002.

[56] G.L. Stewart and K.G. Brown, Human Resource Management: Linking Strategy to Practice. $2^{\text {nd }}$ edition. John Wiley \& Sons, Inc., 2011.

[57] H. Daoud and M. Triki, "Accounting Information Systems in an ERP Environment and Tunisian Firm Performance," The International Journal of Digital Accounting Research, vol. 13, pp. 1-35, 2013.

[58] U. Sekaran and R. Bougie, Research Methods for Business: A SkillBuilding Approach. $6^{\text {th }}$ edition. John Wiley \& Sons, Ltd., 2013

[59] S. Effendi and T. Tukiran, Metode Penelitian Survei. Penerbit LP3ES, Jakarta, 2012

[60] A. Bryman, Social Research Methods. $4^{\text {th }}$ edition. Oxford University Press, 2012

[61] R.M. Kaplan and D.P. Saccuzo, Psychological Testing, Principles, Aplications. And Issues. $6^{\text {th }}$ ed. Thomson Wadsworth, Belmont USA, 2005 .

[62] D.R. Cooper and P.S. Schindler, Business Research Methods. $12^{\text {th }}$ edition. Mc.Graw-Hill Irwin, 2014. 